\title{
Program Terapi Rehabilitasi Kecemasan Pecandu Narkoba dengan Metode Sujok Di Ponpes Salafiyah Sabilul Hikmah Malang
}

\author{
Mayang Wulandari ${ }^{1,}$ Chantika Mahadini ${ }^{2}$, Amal Prihatono ${ }^{3}$, \\ Willie Japaries ${ }^{4}$
}

Prodi Akupunktur Institut Teknologi Sains dan Kesehatan RS dr Soepraoen 1,2,3 Prodi Dharma Usada STAB Nalanda ${ }^{4}$ mayang.wulandari2017@gmail.com

\begin{abstract}
Goals of service. The Community Service Program (PKM) on Drug Addicts Anxiety Rehabilitation Therapy Program with the Sujok Method at Ponpes Salafiyah Sabilul Hikmah Malang aims to optimize the role of Islamic boarding school caregivers in an effort to socialize the movement of drug-free street children by providing counseling on tips for eliminating the anxiety of drug addicts who are addicted to drug undergoing therapy at the boarding school to stop drug use. Methods The PKM implementation team conducted counseling on how to overcome anxiety using therapeutic tools, namely massage rings, providing counseling materials, giving questionnaires about massage ring therapy, donating medicine boxes, providing digital weights, providing digital blood pressure checkers used when providing health services to patients. the caregivers of the Salafiyah Sabilul Hikmah Islamic Boarding School in Malang. Results and implications. After being given counseling about the use of ring therapy, they understand how to deal with anxiety by doing self-therapy every day for 5 minutes or 3 times or more and are able to teach other friends who feel anxious.
\end{abstract}

Keywords: Therapy, Rehabilitation, Anxiety, Drug Addict, Sujok

\begin{abstract}
Abstrak
Tujuan. Program Pengabdian Kepada Masyarakat (PKM) Tentang Program Terapi Rehabilitasi Kecemasan Pecandu Narkoba dengan Metode Sujok Di Ponpes Salafiyah Sabilul Hikmah Malang bertujuan untuk mengoptimalkan peran pengasuh ponpes dalam upaya mensosialisasikan gerakan anak jalanan bebas narkoba dengan cara mengadakan penyuluhan tentang kiat-kiat menghilangkan kecemasan pecandu narkoba yang menjalani terapi di ponpes untuk menghentikan pemakaian narkoba. Metode. Tim pelaksana PKM melakukan penyuluhan tentang cara mengatasi kecemasan menggunakan alat terapi yaitu cincin pijat, memberikan materi penyuluhan, memberi kuesioner tentang terapi cincin pijat, memberi sumbangan kotak obat, memberikan timbang badan digital, memberikan alat pemeriksa tekanan darah digital yang digunakan saat memberikan pelayanan kesehatan kepada para
\end{abstract}


pengasuh Ponpes Salafiyah Sabilul Hikmah Malang. Hasil dan implikasi. Setelah diberikan penyuluhan tentang penggunaan terapi cincin mereka mengerti cara mengatasi kecemasan dengan melakukan terapi mandiri setiap hari selama 5 menit bisa 3 kali atau lebih dan mampu mengajari teman lain yang merasa cemas.

Kata Kunci : Terapi, Rehabilitasi, Kecemasan, Pecandu Narkoba, Sujok

\section{PENDAHULUAN}

Pondok Pesantren Sabilul Hikmah didirikan oleh Gus Ubaidilah Hamid pada tahun 2002, pada tahun 2010 diregistrasikan sebagai pondok resmi sesuai ketentuan pemerintah Republik Indonesia beralamat di Jl. Cakalang 190 RT/ RW 04/02 Kelurahan Polowijen Kecamatan Blimbing Malang Provinsi Jawa Timur. Seiring waktu, jamaah sholawat Sabilul Hikmah melakukan beberapa kegiatan sosial salah satunya adalah kepedulian terhadap anak jalanan yang tersentuh narkoba dan miras. Dengan latar belakang broken family, tidak lulus pendidikan dasar, banyak juga yang dibawah umur, harus mencari uang sendiri untuk bertahan hidup, menyerap banyak hal negatif dan tidak pernah mengenal maupun belajar tentang Islam. Berdasarkan wawancara pada kunjungan pendahuluan ke Ponpes Salafiyah Sabilul Hikmah Malang pada 18 November 2019 didapatkan jumlah anak asuh seluruhnya 95 orang, jumlah tenaga pengelola 10 orang, terdiri atas pimpinan pendok pesantren, sekretaris, bendahara, seksi rehabilitasi, seksi keamanan, seksi kebersihan, seksi konsumsi, guru Al Quran, guru sejarah, guru akhlaq dan guru hadist. Terdapat beberapa ruang yaitu ruang tidur ada 6 kamar, 1 kantor pengurus, aula, 2 ruang interaksi, 5 kamar mandi, 1 ruang poskestren, dan 2 ruang pembelajaran. Ponpes Salafiyah Sabilul Hikmah Malang memiliki jadwal kegiatan untuk para anak jalanan yang cukup padat, sejak pagi pukul 4.30 mereka harus bangun untuk sholat Subuh dan Istighozah, diikuti kegiatan mengaji Al Quran, senam pagi, membersihkan area pondok, istirahat dan mandi pagi, makan pagi, melakukan kegiatan ketrampilan, sholat Dhuhur, terapi, makan siang, istirahat dan mandi, sholat Ashar, pendidikan madrasah, makan sore, sholat Magrib dan Istighozah dan membaca Yasin, sholat Isya' dan Istighozah, kejar paket A B C, terapi, dan diakhiri dengan istirahat tidur malam. Para anak asuh berasal dari kota / kabupaten Malang juga dari luar Malang, mereka tinggal di ponpes karena keinginan pribadi karena ingin sembuh dari ketergantungan narkoba dan ingin mempelajari Islam. Berdasarkan studi pendahuluan yang dilakukan pada 18 November 2019 didapatkan permasalahan yang dialami mitra yaitu adanya dana operasional yang tersendat karena swadaya ponpes sendiri, Anak asuh sukar diatasi karena sudah terlalu lama menggunakan narkoba sehingga sering marah, pusing, menarik diri, cemas, dan mengalami sukar untuk tidur karena kecemasannya, keperluan dasar P3K masih minim. Berdasarkan uraian permasalahan yang dihadapi mitra, tim pelaksana PKM telah berdiskusi dengan mitra guna mengkaji permasalahan mana saja yang bisa diselesaikan melalui pelaksanaan program PKM. Akhirnya, tim pelaksana dan mitra sepakat untuk menyelesaikan permasalahan mitra dengan mengadakan pelatihan dan penyuluhan kepada para pengasuh dan pecandu narkoba melalui program PKM pada 4 Agustus 2020. 
Solusi yang ditawarkan terkait permasalahan yang muncul pada mitra, meliputi: Penyediaan sarana dengan memberikan peralatan kesehatan sederhana, obat-obatan P3K, memberi cairan pembersih tangan, dan alat terapi untuk mengatasi kecemasan pecandu berupa cincin untuk pijat, melakukan penyuluhan dengan memberikan penyuluhan cara mengatasi rasa cemas, mudah marah, pusing, dan sukar tidur dengan menempelkan poster-poster di tempattempat yang mudah terlihat, serta cara menggunakan cincin pijat, serta Edukasi yaitu memberikan motivasi dan menambah pengetahuan bagi kelompok mitra dengan penyuluhan mengatasi cemas, mudah marah, pusing, dan sukar tidur. Memberi pengetahuan tentang pentingnya hidup sehat, menjauhi narkoba yang dimulai dari diri sendiri, tidak boleh takut untuk mengatakan tidak pada narkoba, meyakinkan diri sendiri bahwa semua pasti bisa hidup sehat tanpa narkoba sehingga bisa hidup ditengah masyarakat. Program PKM ini bertujuan untuk mengoptimalkan peran ponpes dalam upaya mensosialisasikan gerakan anak jalanan bebas narkoba dengan cara mengadakan penyuluhan tentang kiat-kiat menghilangkan kecemasan pecandu narkoba yang menjalani terapi di ponpes untuk menghentikan pemakaian narkoba.

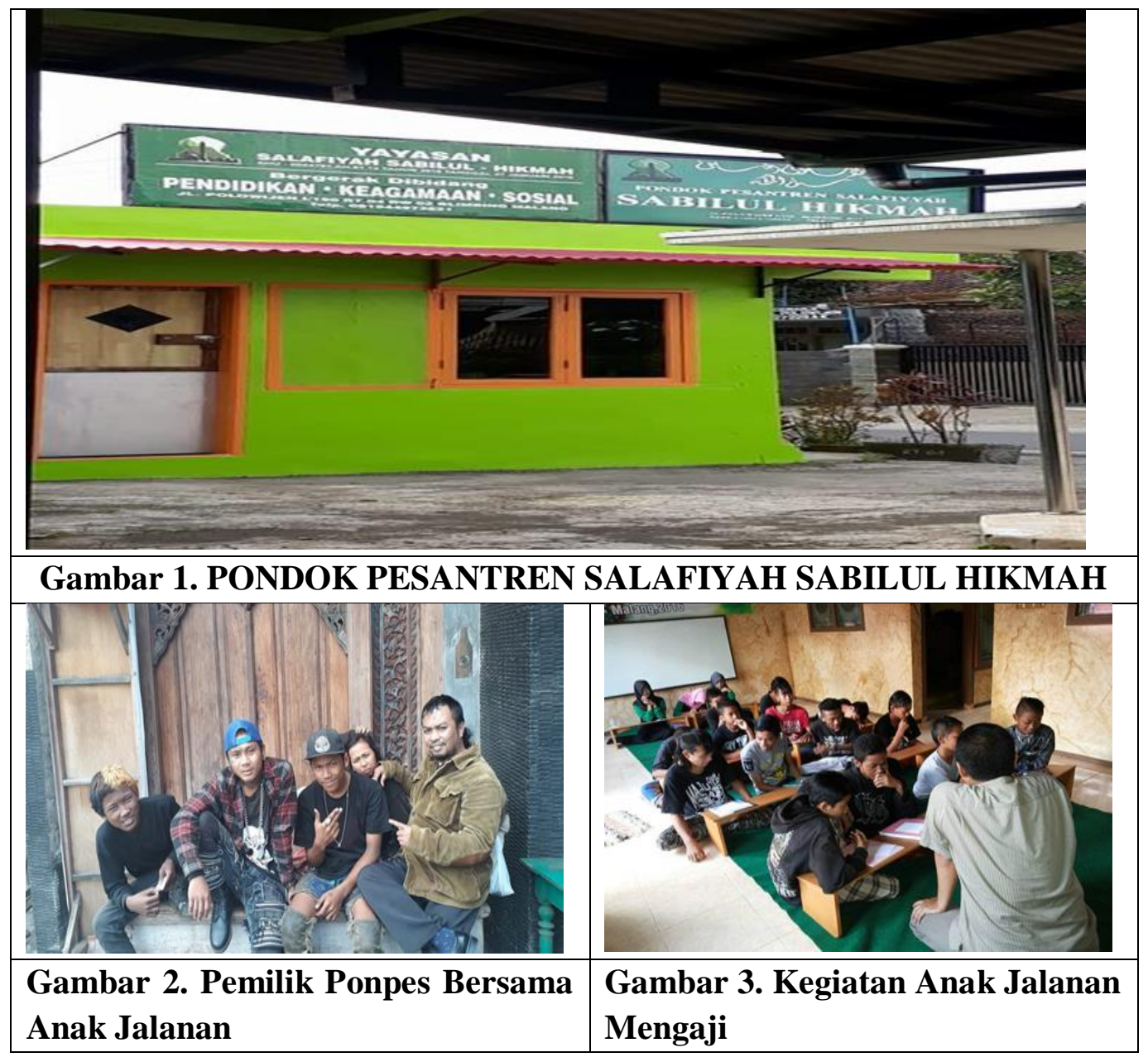




\section{METODE}

Pada tahap pelaksanaan ini kelompok para pengasuh dan anak jalanan pecandu narkoba Ponpes Salafiyah Sabilul Hikmah Malang diajak secara bersama-sama untuk melaksanakan kegiatan yang sudah disepakati bersama dengan susunan sebagai berikut: yaitu Edukasi memberikan motivasi dan menambah pengetahuan bagi kelompok mitra dengan penyuluhan mengatasi cemas, mudah marah, sering pusing, dan sukar tidur, pemberian sarana yaitu memberikan peralatan kesehatan sederhana, obat-obatan $\mathrm{P} 3 \mathrm{~K}$, memberi cairan pembersih tangan, dan alat mengukur berat, dan pengukur tekanana darah, dan penyuluhan memberikan pengetahuan cara mengatasi rasa cemas, mudah marah, sering pusing, dan sukar tidur dengan metode terapi cincin sujok dan menempelkan poster-poster di tempat-tempat yang mudah terlihat.

Tahap ini merupakan inti program, kelompok pengasuh dan anak jalanan pecandu narkoba Ponpes Salafiyah Sabilul Hikmah Malang diberikan penyuluhan tentang kecemasan, marah, sering pusing, dan sukar tidur, pemberian sarana yaitu alat kesehatan dan cara penggunaan alat terapi cincin pijat. Pada awal kegiatan edukasi pada kelompok mitra dilakukan penyuluhan tentang kecemasan, mudah marah, sering pusing, dan sukar tidur. Sebelaum memberi pengetahuan tentang bahaya narkoba, pentingnya hidup sehat yang dimulai dari diri sendiri para pecandu diberikan kuesioner tentang tingkat kecemasan apabila lama tidak menggunakan narkoba, setelah itu diberikan penyuluhan para pengasuh dan anak jalanan pecandu narkoba Ponpes Salafiyah Sabilul Hikmah Malang diajarkan cara menggunakan alat terapi yaitu cincin pijat. Di akhir acara para pengasuh dan anak jalanan pecandu narkoba Ponpes Salafiyah Sabilul Hikmah Malang diberi cincin untuk terapi untuk mereka gunakan sendiri atau membantu teman yang lain dan diminta untuk melakukan terapi sendiri minimal sehari 3 kali. Beberapa hari kemudian kami kembali memberi kuesioner tentang kecemasan apakah ada penurunan sejak penggunaan terapi cincin sujok, ternyata semua mengalami penurunan, bisa dilihat dari sudah tenang tidak sering marah-marah, tidak gelisah, tidur bisa nyenyak, dan bisa mengikuti kegiatan pondok tanpa harus dipaksa. Luaran dari pengabdian ini adalah jasa yang diberikan kepada mitra suatu terapi untuk menurunkan kecemasan, adanya poster tentang kiat menurunkan kecemasan, dan target untuk membuat modul terapi tentang kecemasan. Target pelaksanaan adalah menurunkan kecemasan pecandu narkoba dengan metode terapi sujok. Adapun kondisi anak jalanan setelah mendapat terapi mereka lebih tenang, melakukan kegiatan pondok tanpa paksaan, dan bisa tidur nyenyak, hal ini membuat mereka tetap menggunakan cincin terapi sujok untuk menerapi diri mereka sendiri bahkan menolong teman.

\section{HASIL DAN PEMBAHASAN}

\section{Hasil}

Kegiatan Pengabdian Kepada Masyarakat dengan program kemitraan "Program Pengabdian Kepada Masyarakat (PKM) Tentang Program Terapi Rehabilitasi Kecemasan Pecandu Narkoba dengan Metode Sujok Di Ponpes Salafiyah Sabilul Hikmah Malang” dimulai 
pada 4 Agustus - 2 September 2020. Focus kegiatan dilaksanakan di tempat mitra yaitu Ponpes Salafiyah Sabilul Hikmah Malang, mitra adalah para anak jalanan pecandu narkoba yang ditampung di Ponpes tersebut. Sebelum memberikan penyuluhan tentang cara terapi mengatasi kecemasan pada ketergantungan narkoba menggunakan cincin sujok, mitra diminta untuk mengisi kuesioer, dari 14 orang yang ada kebanyakan merasa cemas, sering marah, sukar tidur, tidak mau ikut kegiatan rutin pondok, dan sering gelisah. Setelah mengisi kuesioner mereka diberi penerangan dan pelatihan cara menggunakan cincin sujok untuk mengatasi kecemasan. Cincin sujok dapat digunakan sehari 3 kali dengan cara mengurut dari atas ke bawah pada jari tangan dari arah kuku kearah telapak tangan, terapi dilakukan selama 5 sampai 10 menit setiap hari. Dari terapi tersebut ada perubahan dalam mengurangi kecemasan mitra akibat terlepas dari narkoba. Hal ini nampak dari kuesioner tingkat kecemasan yang tadinya sedang menjadi ringan, dari pertanyaan yang sebelumnya sukar tidur menjadi nyenyak, malas untuk mengikuti kegiatan pesantren jadi mau ikut kegiatan, yang sering bangun siang menjadi bangun pagi, emosi juga lebih terkendali, semua kegelisahan berkurang berimbas pada penurunan nilai kecemasan dari $15.8 \%$ menjadi $12.4 \%$

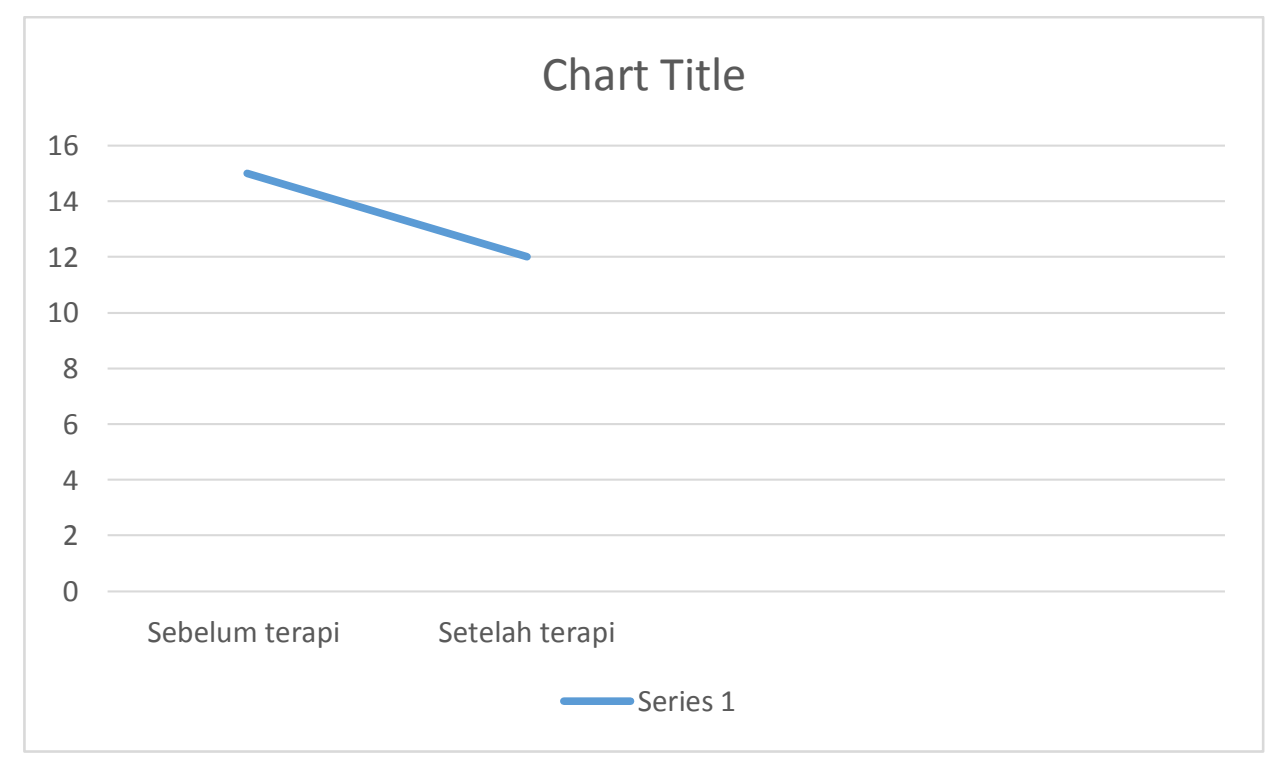

Grafik 1. Kondisi Kecemasan Pecandu Narkoba di Pondok Pesantren Salafiyah Sabilul Hikmah Malang.

\section{Pembahasan}

Terapi sujok adalah metode baru, menjadi bagian dari akupunktur, sederhana, efektif dan mudah dipraktikkan oleh semua orang. Metode yang sepenuhnya terkonsentrasi pada tangan dan kaki. Di Korea su berarti tangan dan jok - kaki. Sistem penyembuhan korespondensi yang ditanamkan di tangan dan kaki adalah sistem penyembuhan independen yang sempurna, yang logis, sistematis, terperinci dan diakui oleh seluruh dunia. Ketika bagian tubuh ditekan terasa 
sakit dan secara subjektif dirasakan sebagai titik rasa sakit maka koresponden merujuk organ dengan cara yang sama (D'Alberto, 2006). Otak mengendalikan semua organ dan sistem tubuh. Jika suatu organ sakit di zona korespondensi otak titik nyeri muncul. Titik ini sesuai dengan area otak, yang sesuai dengan organ yang sakit. Stimulasi titik ini membuat efek penyembuhan lebih kuat. Area otak yang dirangsang dengan memijatkan cincin sujok di daerah korespondensi di jari akan memberikan ketenangan dan rasa rileks, hal ini dapat dilihat dari jawaban dari kuesioner mitra yang mayoritas kecemasannya menurun (Ivanov, 1996).

\section{KESIMPULAN}

Tingkat kecemasan yang tadinya sedang menjadi ringan, dari yang sebelumnya sukar tidur menjadi nyenyak, malas untuk mengikuti kegiatan pesantren jadi mau ikut kegiatan, yang sering bangun siang menjadi bangun pagi, emosi juga lebih terkendali, semua kegelisahan berkurang berimbas pada penurunan nilai kecemasan dari $15.8 \%$ menjadi $12.4 \%$. Terapi sujok merupakan terapi baru yang murah, mudah, tanpa efek samping, dan sudah terbukti dapat menurunkan kecemasan, hendaknya digunakan untuk pecandu narkoba dengan cakupan yang lebih luas untuk mendukung rehabilitasi dan bekerja sama dengan Badan Narkotika Nasional.

\section{DAFTAR PUSTAKA}

Assauri, S. 2013. Manajemen Pemasaran. Rajawali Pers.

C.P. 2012. Effects of Acupuncture on Symptoms of Anxiety in women Undergoing in vitro fertilization: A Prospective Randomized Controlled Trial. Acupunct Med 30 (2):85-88

Carney, M.M. \& Kivlahan, D.R. (1995). Motivational subtypes among veteran seeking substance abuse treatment: Profiles based on stages of change. Psychology of Addictive Behaviors

D'Alberto, A. 2006. Understanding Cocaine Addiction According to Chinese Medicine Theory. Chinese Medicine Times vol.1, Issue 1

Hawari, D. 2006. Penyalahgunaan dan Ketergantungan NAPZA (Narkotika, Alkohol dan Zat Adiktif). Jakarta: FKUI. p. 4

Hesse, M. 2009. Integrated Psychological Treatment for Substance Use and Co- morbid Anxiety or Depression vs. Treatment for Substance Use Alone. BMC Psychiatry 9:6

Park, Jae Woo. 2001. Be Your Own Su Jok Doctor. Academy Jaipur, India

Park, Jae Woo. 2001. Su Jok For Everybody. Academy Jaipur, India 